\title{
NATO and the South Caucasus: Armenia, Azerbaijan, and Georgia on Different Tracks
}

\author{
Martin Malek
}

\section{Introduction}

In 2002, NATO Secretary-General Lord George Robertson stated that, "for the North Atlantic Treaty Organization, the Caucasus is of no special relevance." ${ }^{1}$ Up until now, this attitude has not changed fundamentally, even though the region obviously attracts the Alliance's attention more than it did in the 1990s. NATO's stance toward the South Caucasus has always provoked much more and stronger reactions in Russia than in the political, media, and public realms of the Alliance's member states.

In 1999, within the framework of the Euro-Atlantic Partnership Council (EAPC), an Ad Hoc Working Group on Prospects for Regional Cooperation in the Caucasus was established, placing primary focus on defense and economics issues, civil and emergency planning, science and environmental cooperation, and information activities. However, to date there is no overall comprehensive format for NATO cooperation with the South Caucasus that would even come close to its "strategic partnership" with the EU, its concept of "special relations" with Russia and Ukraine, the Mediterranean Dialogue, or the South East European Initiative. Only in 2004-i.e., a full thirteen years after the dissolution of the USSR, which was closely followed by the independence of Armenia, Azerbaijan, and Georgia-U.S. diplomat Robert Simmons was appointed as NATO’s first Special Envoy for the South Caucasus and Central Asia.

The prospects for joint initiatives with NATO are inevitably negatively influenced by the fact that the armies of all South Caucasian republics are far from meeting NATO standards and requirements, even though especially Georgia and Azerbaijan have been declaring that they hope to introduce and achieve these standards sooner rather than later. This applies to such issues as democratic control of the armed forces, soldiers' human and civil rights, as well as their social status. At times in these nations, soldiers did not even receive victuals, and their low pay was disbursed with monthlong delays or not at all. This not only led to low morale within the armed forces, massive conscientious objections, and desertions of considerable numbers of troops, but

Dr. Martin Malek is a civilian researcher at the Institute for Peace Support and Conflict Management of the National Defense Academy in Vienna. He is the Austrian representative to the Regional Stability in the Greater Black Sea Area Working Group of the PfP Consortium. His areas of expertise are theories of state failure, theories of ethnic conflict, and security and military policy in the CIS (especially Russia, Ukraine, and the South Caucasus). The author wishes to thank Ernst Felberbauer of the Geneva Centre for the Democratic Control of Armed Forces (DCAF) for his assistance in the preparation of this paper.

1 Cited in Mikhail Vignanskiy, "Gamardzhoba, NATO! Gruziya vstupaet v Alyans otdelno ot sobstvennoy armii,” Vremya Novostey (19 November 2002), 2. Notwithstanding this “disrespect,” Baku State University awarded Robertson an honorary doctorate. 
even to mutinies of some units, especially in Georgia. Corruption within the governmental agencies accountable for security and defense also has an influence on international military cooperation. ${ }^{2}$

This essay will review activities between NATO and South Caucasus, placing a special focus on the "Russian factor" within the region and the "frozen conflicts" in Azerbaijan and Georgia.

\section{Principal Positions Towards NATO}

\section{Armenia}

Armenia has not explicitly set for itself the goal of NATO membership. This would be totally incompatible with its tight military and political attachment to Russia. And Armenia is the only South Caucasian member republic of the CIS Collective Security Treaty Organization, or CSTO. ${ }^{3}$ Armenia's membership in the CSTO, and its close relationship with Russia overall, is generally not opposed in Armenian domestic political discourse. Another obstacle to a push for NATO membership within Armenia is the nation's decidedly friendly political and economic relationship with Iran.

President Robert Kocharyan declared that joining NATO would affect Armenia's relations with neighboring countries and would barely improve its national security. His successor Serge Sarkisyan (who served as Minister of Defense from 1993-95 and 2000-07, then as Prime Minister) has made similar indications. Consequently, this course was documented in Armenia's "National Security Strategy," which was adopted in a meeting of the National Security Council of Armenia on 26 January 2007. This document clearly grants greater priority to cooperation with Russia (bilateral) and to cooperative efforts that take place within the framework of the CSTO (multilateral) than to interactions with other alliances, above all NATO. ${ }^{4}$ As was to be expected, this approach was continued in Armenia's Defense Doctrine, which was signed by President Kocharyan on 25 December 2007. This document makes clear that the "strategic partnership” with Russia will remain the bedrock of Armenia's security policy. Only a single paragraph of the document mentions

2 Peculation of foreign military aid took place to such an extent that the Georgian Ministry of Defense advised NATO to send only material goods in the future; see Dursun Dzlieradze, “Georgia: NATO Hopes on Hold,” IWPR's Caucasus Reporting Service, No. 106 (20 November 2001).

3 This is a CIS military alliance with a provision for military assistance in case of attack (like in the North Atlantic Treaty), to which Armenia, Belarus, Kazakhstan, Kyrgyzstan, Russia, Tajikistan, and Uzbekistan currently belong. Azerbaijan and Georgia had left its predecessor body, the Collective Security Treaty, in 1999.

4 National Security Strategy (approved at session of the Armenian National Security Council at the presidential office on 26 January 2007), Appendix of Presidential Decree NH-37-N of 7 February 2007; available at www.mil.am/eng/index.php?page=49 (accessed 24 August 2007). 
cooperation with the North Atlantic Treaty Organization and its member partner states within the frameworks of the Euro-Atlantic Partnership Council and Partnership for Peace program. To develop prospective and proper relations and developing interoperable capabilities with the NATO, the Republic of Armenia implements the Individual Partnership Action Plan with NATO and participates in the NATO Planning and Review Process, and carries out bilateral military cooperation programs with the NATO members and partner states. ${ }^{5}$

Comments from Armenia on the rounds of NATO enlargement accomplished in 1999 and 2004 ranged from the skeptical to the outspokenly critical. Kocharyan repeatedly criticized Georgia's NATO membership bid (see below), at the same time attesting to Russia's "stabilizing role in the Caucasus." ${ }^{6}$ Unmistakably, NATO is facing image problems in Armenia primarily for the reason that Turkey is a member state. In Armenia, Turkey is often blamed for obstructing Armenian cooperation with NATO. Yet at the same time, Yerevan has for a long time maintained very good relationsboth political and security-related-with another NATO member, Greece. Among other areas, cooperation between Yerevan and Athens has included the training of Armenian officers in Greek military academies.

During the last fifteen years, supporters of Armenian accession to NATO have never even come close to a firm hold on leadership positions, neither in politics, media, nor within the broader public sphere. The Armenian executive branch (the president and the government) has always been convinced that cooperation with the Alliance is possible without membership ambitions, a view that Brussels has never contradicted. Parliament Speaker Artur Baghdasaryan tried to deviate from the Armenian mainstream in an interview with the German daily Frankfurter Allgemeine Zeitung in April 2006. He stated that, since Armenia's future would lie within NATO and EU, Russia should not "block our way to Europe." Kocharyan immediately and vehemently disagreed, and many Armenian politicians and media outlets joined him. Baghdasaryan then rephrased his statement, claiming that NATO membership should be envisioned merely as the end point of a long process, but the damage to his public career had been done. ${ }^{7}$ He had to step down in May 2006, and proclaimed the withdrawal of his party, Orinats Yerkir, from the government.

Opinion polls in Armenia regarding NATO membership keep showing a wide deviation, depending on both the source of the study and the client who commissioned it. According to a survey conducted by the U.S. Agency for International Development and the International Republican Institute in 2007-if it is to be believed - the climate of public opinion towards NATO in Armenia is mellower than one might expect considering its internal and external political framework, as well as the enduring influence of Russian media in the country. According to this poll, 45 percent of Armenian citi-

5 The Military Doctrine of the Republic of Armenia, Appendix of Presidential Decree NH308-N of 25 December 2007, available at www.mil.am/eng/index.php?page=104 (accessed 10 April 2008).

6 Cited in RFE/RL Armenia Report (22 October 2001).

7 RFE/RL Newsline 10:80, Part I (3 May 2006). 
zens are "somewhat" or "strongly" opposed to accession to NATO, while 40 percent are "somewhat" or "strongly" in favor of it. Kocharyan declined any interest in EU membership, although it would meet with an 80 percent acceptance rate among the Armenian public. ${ }^{8}$

\section{Azerbaijan}

Vafa Guluzade, foreign policy advisor to Azerbaijani President Heydar Aliev, has been very much in favor of NATO membership for Azerbaijan since the 1990s, which met with overwhelmingly negative or even harsh reactions in Russia, and silence in Brussels. Consequently, the leadership in Baku itself has avoided any clear statements, and has instead pursued forms of cooperation with the Alliance beneath the level of full membership. In February 2007, President Ilkham Aliev told Deutsche Welle that it is well known both in Brussels as well as in Baku that Azerbaijan is not yet ready for NATO membership, and that he would not want to "set any unrealistic goals." A whole chapter in Azerbaijan's "National Security Concept” (issued on 23 May 2007) is dedicated to the "Integration into European and Euro-Atlantic Structures," which the document even labels a "strategic goal." ${ }^{, 10}$ Furthermore, the "establishment of operational forces interoperable with those of NATO member states" is being mentioned. However, the goal of NATO membership is not mentioned in this document. ${ }^{11}$

It is highly probable that Baku's political approach with respect to the Alliance is influenced by the position of its powerful neighbors. Elkhan Mekhtiev judged that Azerbaijan wants to avoid the kind of pressure that Russia currently is exerting on Georgia. The Baku-based foreign policy analyst further opined that nobody in Azerbaijan wants a conflict with Moscow simply over the issue of NATO membership: "Azerbaijan's leaders understand that if they act like Georgia, the troubles that await them will be even worse."12 Azerbaijan's relations with Iran were strained due to several reasons, one of which is that Tehran perceives Azerbaijan's foreign policy as being “pro-Western," and therefore highly objectionable. In August 2007, Iranian President Mahmud Ahmadinejad visited Baku for the first time. Ilkham Aliev declared on

8 “Armenia Says not Aiming for NATO, EU Membership,” RFE/RL Features Article (16 July 2007). However, official documents of the Armenian Defense Ministry contain the following phrase: "Consistent with its objective to integrate into European structures and institutions, Armenia intends to enhance its cooperation with the European Union and to seek closer institutional compatibility, with the ultimate aim of full membership” (Armenia's Commitments Under Individual Partnership Action Plan With NATO, available at www.mil.am/eng/ index.php?page=50 (accessed 10 April 2008).

9 Cited in Ilkham Aliev, “Azerbaidzhan mozhet vstupit v NATO,” Day.az (21 February 2007); available at www.day.az/print/news/politics/71190.html (accessed 22 August 2007). Relations with Russia are dealt with in a small abstract (Chapter 4.1.5.1).

11 National Security Concept of the Republic of Azerbaijan; available at www.mfa.gov.az/ ssi_eng/foreign_policy/inter_affairs/nsc/NSC.pdf (accessed 15 August 2007).

12 Cited in Jasur Mamedov, “Azerbaijan Tiptoes Towards NATO,” IWPR's Caucasus Reporting Service, No. 367 (23 November 2006). 
this occasion that "our positions are identical on all points."13 This announcement was especially unexpected, since Iran's refusal to accept rapprochement with NATO (not to mention membership) by any South Caucasian republic is beyond doubt, as is Tehran's objection to any NATO and/or U.S. presence in the region.

\section{Georgia}

President Eduard Shevardnadze's position with respect to Georgia's potential NATO membership was ambivalent. In 1999, he declared that the time "to knock on NATO's door" would come in 2005. At the end of 2000, he stated at an international conference in Tbilisi that his country would be ready to join the Alliance by 2004. Nevertheless, this goal was beyond reach, and merely served to increase Moscow's already strong concerns. At the same time, Shevardnadze announced-not coincidentally in interviews with Russian media-that Georgia could declare itself neutral by $2005 .{ }^{14}$ Sometimes, however, he referred to NATO membership as an unrealistic prospect in the near future. $^{15}$

On 13 September 2002, at a time when relations with Russia were very strained, Georgia's parliament opted in favor of NATO membership, a step that was officially reconfirmed by Shevardnadze when he was invited as a guest to NATO's Prague Summit in November 2002. Furthermore, he announced that, as the president of a Black Sea state, he was "particularly satisfied that the invitations have been extended to Romania and Bulgaria. This brings the Black Sea area into NATO's sphere of interests and adds a new dimension to its security." ${ }^{16}$ On 28 December 2002, Georgia’s National Security Council decided to set up a "State Program for Georgia's Euro-Atlantic Integration.” This level of variability in Georgian policy definitely came to an end after the "Rose Revolution" took place in November 2003, ousting Shevardnadze and paving the way for Mikheil Saakashvilis' presidency, which started in 2004. Since then, the leadership in Tbilisi has set the clear goal of NATO membership. It is mentioned in all relevant documents, and-more importantly—is being actively pursued by Georgia's de facto foreign and security policy.

The document "Georgia's Commitments Under the Individual Partnership Action Plan (IPAP) with NATO: 2004-2006” openly stated: “Georgia is aware of the progress

13 Cited in RFE/RL Newsline 11:155, Part I (22 August 2007).

14 Jean-Christophe Peuch, "Georgia: Shevardnadze Says His Country Might Choose Neutrality,” RFE/RL (6 February 2001). In the spring of 1999, Shevardnadze unexpectedly called his country's prospective NATO membership a “joke”; see Arkady Dubnov, "Georgia joining NATO? But that’s a joke,” Moscow News 17 (12-18 May 1999): 5. Dzlieradze, "Georgia: NATO Hopes on Hold."

16 Statement by President of Georgia Eduard Shevardnadze at the EAPC Summit, Prague, 22 November 2002; available at www.nato.int/docu/speech/2002/s021122h.htm (accessed 2 September 2007). 
it needs to make prior to advancing its NATO membership aspirations."17 The "Foreign Policy Strategy 2006-2009" underscored the goal of NATO membership, stating that relations with the EU should be "enhanced," while membership in the Commonwealth of Independent States (CIS) is questioned. ${ }^{18}$ The "National Security Concept of Georgia," adopted in 2005 by the Georgian parliament, outlines huge reforms in the defense sector with the aim of reaching NATO standards. Georgia, as further stated, welcomes the admission of new member states into NATO and EU. It regards the North Atlantic Pact "as an organization of collective defense that is the central mechanism for providing security and stability in the Euro-Atlantic area. Georgia's cooperation with NATO contributes to the strengthening of democratic values in the country, the accomplishment of democratic reforms, especially in the field of defense, as well as the establishment of a secure and stable environment.", Also in 2005, the "National Security Concept," which is regarded a core element of Georgia's "National Military Strategy," was adopted with the aim of providing guidelines for the nation's defense policy until 2010. As a matter of fact, the entire document was influenced by the strong desire to join NATO: "The ultimate goal is a highly capable, NATO-interoperable Armed Force able to contribute to any NATO-led military operations."20 NATO membership is also mentioned prominently in the foreign minister's "Foreign Policy Directives 2007," which state that a Membership Action Plan (MAP) should be achieved. ${ }^{21}$ The importance of this question from Tbilisi's point of view is also documented by the fact that Georgia is the only South Caucasian republic with a special member of government responsible for European and Euro-Atlantic integration, namely Vice-Premier Giorgi Baramidze (who was minister of defense for a few months in 2004). However, NATO’s Summit in Bucharest in April 2008 denied Georgia a MAP.

The Georgian leadership's desire to join NATO is rarely contested in domestic politics. On 12 March 2007, the leaders of the most important Georgian parties-put-

17 In the document “Georgia's Commitments Under the Individual Partnership Action Plan (IPAP) with NATO: 2004-2006,” available at www.natoinfo.ge/?l=E\&mm=6\&sm=4 (accessed 10 August 2007). In June 2007, Georgia released its Strategic Defense Review (SDR) on the basis of the IPAP.

18 Foreign Policy Strategy 2006-2009, 9-10, 20; available at www.cipdd.org/files/ 49_191_ 158284_MFA-ForeignPolicyStrategy2006-2009ENG.pdf (accessed 21 August 2007). Saakashvili has so far not pushed for Georgia to leave the CIS, notwithstanding a parliamentary majority that is skeptical of or opposed to the CIS, and calls for an exit.

19 Ministry of Foreign Affairs of Georgia, “National Security Concept of Georgia,” Chapter 5.4.1; available at www.mfa.gov.ge/index.php?sec_id=24\&lang_id=ENG (accessed 8 July 2007).

20 National Military Strategy of Georgia; available at www.mod.gov.ge/?l=E\&m=3\&sm=3 (accessed 20 August 2007).

21 Ministry of Foreign Affairs of Georgia, “Minister's Directives for 2007”; available at www.cipdd.org/files/49_191_522833_MFADirectives2007.pdf (accessed 21 August 2007). - Nevertheless, an MAP is no guarantee for rapid accession to membership; Albania and Macedonia have been taking part in the MAP since its initiation at NATO's summit in Washington 1999, and Tirana was invited into the Alliance only in 2008. 
ting aside their differences on many other issues—signed the document "On Membership of Georgia in North Atlantic Treaty Organization (NATO)." ${ }^{, 2}$ The parliament approved it unanimously the following day.

Opinion polls (which, however, cannot be conducted in the separatist regions Abkhazia and South Ossetia) revealed a generally high level of support for NATO. The positions of Georgia's most significant ethnic minorities with respect to NATO are not surprising: while 72 percent of ethnic Azerbaijanis are in favor of NATO membership, a majority of Armenians opposes it. ${ }^{23}$ Georgia is so far the only South Caucasian republic where voters have been allowed to decide how to deal with NATO. A nonbinding, advisory referendum on whether to join the Alliance was held on 5 January 2008, together with an early presidential election. According to the official results of the Central Election Commission, 68.37 percent of the total turnout was in favor of NATO membership. ${ }^{24}$

\section{The South Caucasus in NATO's Basic Documents}

The minor importance of the South Caucasus for NATO was made apparent by the fact that the region (or its particular states) was neither mentioned in the Madrid Declaration on Euro-Atlantic Security and Cooperation of NATO's Summit in July 1997 nor in NATO's Strategic Concept of 1999, nor in the Communiqué of the Washington Summit from April 1999. In the declaration of the NATO Summit in Prague, which on 21 November 2002 invited seven post-communist countries to join the Alliance, the South Caucasus was mentioned once, being referred to - together with Central Asiaas a "strategically important region." 25 The Communiqué of the NATO Summit in June 2004 in Istanbul spoke of a "special focus on engaging with our Partners in the strategically important regions of the Caucasus and Central Asia.” And, additionally:

Towards that end, NATO has agreed on improved liaison arrangements, including the assignment of two liaison officers, as well as a special representative for the two regions from within the International Staff. We welcome the decision by Georgia, Azerbaijan, and Uzbekistan to develop Individual Partnership Action Plans with NATO. This constitutes a significant step in these countries' efforts to develop closer

${ }^{22}$ Memorandum of Parliamentary Factions and Political Parties on Georgia's Membership in the North Atlantic Treaty Organization (NATO); available at http://www.parliament.ge/ index.php?lang_id=ENG\&sec_id=98\&info_id=15215 (accessed 21 August 2007).

23 “Azerbaijani Population of Georgia Backs Intentions to Join NATO,” Trend News Agency (9 June 2007); available at http://news.trendaz.com/cgi-bin/readnews2.pl?newsId=938928\& lang=EN (accessed 12 June 2007).

${ }^{24}$ Central Election Commission of Georgia, "CEC Approved the Summary Protocol of Plebiscite,” 18 January 2008; available at http://cec.gov.ge/?que=eng/press-center/bulletin\& info=3698 (accessed 30 April 2008).

25 Prague Summit Declaration, issued by the heads of state and government participating in the meeting of the North Atlantic Council in Prague on 21 November 2002; available at www.nato.int/docu/pr/2002/p02-127e.htm (accessed 23 August 2007). 
Partnership relations with the Alliance. We welcome the commitment of the new government of Georgia to reform. ${ }^{26}$

The declaration of the following NATO Summit taking place at the end of November 2006 in the Latvian capital Riga - the first NATO Summit to be held in a former Soviet republic - mentioned the South Caucasus (together with Moldova) in a single paragraph (no. 43), encompassing three sentences. ${ }^{27}$ Georgia and its very emphatic NATO ambitions received more attention. The document states that an "Intensified Dialogue” will be led with Georgia, "without prejudice to any eventual Alliance decision” (paragraph 37). Consequently, membership was not explicitly mentioned, much less a concrete invitation for opening membership negotiations - a step that is much desired in Georgia (and feared in Russia). More in the same vein follows in paragraph 39: "We welcome the commencement of an Intensified Dialogue with Georgia as well as Georgia's contribution to international peacekeeping and security operations. We will continue to engage actively with Georgia in support of its reform process. We encourage Georgia to continue progress on political, economic and military reforms, including strengthening judicial reform."28

The Declaration of NATO's Bucharest Summit (April 2008) expressed “concern” with the persistence of regional conflicts in the South Caucasus and support for the territorial integrity, independence, and sovereignty of Armenia, Azerbaijan, and Georgia: "We will continue to support efforts towards a peaceful settlement of these regional conflicts, taking into account these principles" (paragraph 43). Furthermore, the Alliance "welcomed" Georgia and Ukraine's membership aspirations. "MAP is the next step for Ukraine and Georgia on their direct way to membership," the declaration stated. "Today we make clear that we support these countries' applications for MAP. Therefore we will now begin a period of intensive engagement with both at a high political level to address the questions still outstanding pertaining to their MAP applications” (paragraph 23). ${ }^{29}$

26 NATO Press Release (2004) 096, Istanbul Summit Communiqué, issued by the heads of state and government participating in the meeting of the North Atlantic Council, 28 June 2004, abstracts 3 and 31; available at www.nato.int/docu/pr/2004/p04-096e.htm (accessed 23 August 2007).

NATO Press Release (2006) 150, Riga Summit Declaration, issued by the heads of state and government participating in the meeting of the North Atlantic Council in Riga on 29 November 2006 (29 November 2006); available at www.nato.int/docu/pr/2006/p06-150e.htm (accessed 23 August 2007).

Ibid.

29 NATO Press Release (2008) 049, Bucharest Summit Declaration, issued by the heads of state and government participating in the meeting of the North Atlantic Council in Bucharest on 3 April 2008 (3 April 2008); available at www.nato.int/docu/pr/2008/p08-049e.html (accessed 7 April 2008). 


\section{Cooperation between NATO and Nations in the South Caucasus}

\section{General Provisions}

Cooperation efforts between the Alliance on the one hand and Armenia, Azerbaijan, and Georgia on the other are being pursued at various levels. All three South Caucasian republics have their own missions to NATO and have established contacts with education and training facilities like the NATO School in Oberammergau, the NATO Defense College in Rome, and the PfP Training Center in Ankara. The PfP has become "NATO's chief tool for deepening its military cooperation with the states of the South Caucasus."30 Armenia, Azerbaijan, and Georgia are more or less intensively involved in numerous PfP activities that cannot be further elaborated upon (and definitely not assessed) in this essay. ${ }^{31}$ The area of scientific cooperation encompasses issues that would normally not be considered to belong to NATO's competencies, like the South Caucasus River Monitoring project. The PfP Consortium (PfPC) has participants from all three South Caucasian states. The region is now being addressed by the PfP through the discussions of the Regional Stability in the Greater Black Sea Area Working Group. The Tbilisi-based Georgian Foundation for Strategic and International Studies (GFSIS) was involved in its activities. GFSIS co-founder and Executive Vice-President Temur Iakobashvili was appointed State Minister on Reintegration Issues in January 2008; as such, he is in charge of conflict resolution in Abkhazia and South Ossetia. Generally, Georgia is very active in the PfP, even though expectations and hopes are not always met by outcomes.

The report of a delegation of NATO's Parliamentary Assembly called Armenia an "enthusiastic participant in PfP activities."32 At the beginning of 2006, the British Caucasus expert Elizabeth Fuller said with respect to Azerbaijan that its "IPAP does not give the impression that Baku considers cooperation with the Alliance a top priority." 33 Baku has nevertheless on many occasions emphasized that it wants to elevate its army to a NATO-level standard, especially by means of the IPAP. ${ }^{34}$ This is a primary goal of Azerbaijan's military academies. The current estimates about the progress achieved so far in the armed forces with respect to achieving NATO standards differ

30 Svante E. Cornell, Roger N. McDermott, William D. O’Malley, Vladimir Socor, and S. Frederick Starr, Regional Security in the South Caucasus: The Role of NATO (Washington, D.C.: The John Hopkins University, Central Asia-Caucasus Institute, 2004), 67.

31 “NATO's cooperation with partners. What does this mean in practice?”, 4 July 2007; available at www.nato.int/issues/cooperation_partners/index.html (accessed 30 August 2007).

32 Frank Cook (United Kingdom), Rapporteur. 168 DSCFC 06 E, “NATO’s Role in South Caucasus Region"; available at www.nato-pa.int/Default.asp?SHORTCUT=998 (accessed 18 August 2007), Article 48.

33 Liz Fuller, “Azerbaijan Still Lacks National-Security, Military Doctrines,” RFE/RL Reports 9:4 (3 February 2006).

34 See, for example, “Azerbaijan Upgrading Navy, Military Airfield under NATO Plan,” BBC Monitoring (9 May 2007); available at www.bbcmonitoringonline.com/mmu?page=77\& action=view\&item=11\&srchid=0021syh\&sw=0 (accessed 10 May 2007). 
widely even within Azerbaijan, ${ }^{35}$ although sources from the administration are generally more optimistic than others, especially from independent think-tanks and experts. ${ }^{36}$

\section{NATO Exercises in the South Caucasus}

Nine NATO member states and six PfP countries, among them Azerbaijan and the host country, participated in the maneuver "Cooperative Partner 2001" in Poti, Georgia, in June 2001. In November 2001, the exercise "Cooperative Determination 2001" took place in Baku. But nine NATO members, Armenia, Azerbaijan, Georgia, and seven other PfP countries did not move any military hardware; it was not a live drill, but rather a command post/computer-assisted exercise that aimed to improve military interoperability for crisis response operations. In June 2002, "Cooperative Best Effort 2002" united some 500 soldiers from NATO and PfP countries in Vaziani, Georgia, near Tbilisi. Armenia, Azerbaijan, Georgia, and Turkey participated. Patrolling, organizing checkpoints, and dispersing crowds were some of the training subjects covered.

Russia had refused NATO's invitation. A year later Armenia hosted a PfP maneuver for the first time- “Cooperative Best Effort 2003," which brought together 400 soldiers from nineteen countries, including Georgia, Russia, and Turkey (the participation of its three soldiers provoked controversy in Armenia). Azerbaijan had refused to take part. "Cooperative Best Effort 2004" should have taken place in September 2004 in Azerbaijan. However, NATO abstained from undertaking the maneuver, since Baku had refused to grant visas to Armenian participants. Not surprisingly, Armenian Foreign Minister Vartan Oskanyan appreciated this step of the Alliance.

\section{Participation in NATO-led Operations}

The allocation of the South Caucasian contingents to the 15,900 soldier-strong peacekeeping force KFOR in Kosovo has made the political preferences of the contributing nations apparent. The Armenian platoon (34 soldiers) is under the command of a Greek battalion. The Azerbaijani motorized platoon (34 soldiers) and the Georgian contingent (182 soldiers) are under Turkish command within the framework of the Multi-National Task Force South (MNTFS), which was established in May 2006. ${ }^{37}$

35 One occasionally encounters the view that the primary reason behind Azerbaijan's pursuit of NATO standards is that it expects to achieve military advantages in comparison with Armenia, in case of renewed conflict over Karabakh. See, for example, Andrew Monaghan, “Azerbaijan's Key Role in the South Caucasus,” Research Paper No. 32 (Rome: NATO Defense College Rome, Academic Research Branch, March 2007), 5.

36 “Azerbaijan Will End Possible Military Reforms by 2015 to Coincide with NATO Standards,” Today.az (15 May 2007); available at www.today.az/news/politics/40864.html (accessed 30 August 2007).

37 NATO, "Multi-National Task Force South, updated 24 December 2007; available at www.nato.int/kfor/structur/units/mntf_south.html (accessed 9 April 2008). KFOR, updated 4 February 2008; available at www.nato.int/kfor/structur/nations/placemap/kfor_placemap.pdf (accessed 9 April 2008). See also The Military Balance 2008 (London: The International Institute for Strategic Studies, 2008), 166, 168, 177. 
THE QUARTERLY JOURNAL

Table 1: Overview of NATO Activities Regarding the South Caucasus

\begin{tabular}{|c|c|c|c|}
\hline & Armenia & Azerbaijan & Georgia \\
\hline $\begin{array}{l}\text { Associated membership of } \\
\text { parliaments in the NATO } \\
\text { Parliamentary Assembly }\end{array}$ & Since 2002 & Since 2002 & Since 1999 \\
\hline Mission to NATO & $\begin{array}{l}\text { Opened in Novem- } \\
\text { ber } 2004 \text { (previ- } \\
\text { ously, Armenia’s } \\
\text { Embassy in Brussels } \\
\text { had represented the } \\
\text { country at NATO) }\end{array}$ & Exists & $\begin{array}{l}\text { Opened on } 22 \text { April } \\
1998\end{array}$ \\
\hline NATO Information Centers & $\begin{array}{l}\text { NATO Information } \\
\text { Center in Yerevan } \\
\text { operational since } \\
\text { November 2006; } \\
\text { officially opened on } \\
12 \text { March } 2007\end{array}$ & $\begin{array}{l}\text { Euro-Atlantic } \\
\text { Center in Baku } \\
\text { opened on } 3 \text { July } \\
\text { 2006, and in } \\
\text { Gandzha in July } \\
2007\end{array}$ & $\begin{array}{l}\text { Active since } 2005 \\
\text { in the following lo- } \\
\text { cations: Tbilisi } \\
\text { (head office); bu- } \\
\text { reaus in Batumi } \\
\text { (Ajara), Kutaisi, } \\
\text { Telavi, and } \\
\text { Chkhalta (Kodori } \\
\text { Valley }^{38} \text { ) }\end{array}$ \\
\hline $\begin{array}{l}\text { North Atlantic Cooperation } \\
\text { Council (NACC) (existed } \\
\text { from 1991-97) }\end{array}$ & Joined in 1991-92 & Joined in 1991-92 & $\begin{array}{l}\text { Joined in April } \\
1992\end{array}$ \\
\hline $\begin{array}{l}\text { Euro-Atlantic Partnership } \\
\text { Council (EAPC), successor } \\
\text { of NACC since } 1997\end{array}$ & Member since 1997 & $\begin{array}{l}\text { Member since } \\
1997\end{array}$ & Member since 1997 \\
\hline $\begin{array}{l}\text { Partnership for Peace (PfP) } \\
\text { Framework document (first } \\
\text { signed January 1994) }\end{array}$ & $\begin{array}{l}\text { Signed } 5 \text { October } \\
1994\end{array}$ & $\begin{array}{l}\text { Signed } 4 \text { May } \\
1994\end{array}$ & $\begin{array}{l}\text { Signed } 23 \text { March } \\
1994\end{array}$ \\
\hline $\begin{array}{l}\text { Individual Partnership } \\
\text { Program (IPP) }\end{array}$ & Adopted in 1996 & Adopted in 1996 & Adopted in 1996 \\
\hline $\begin{array}{l}\text { Planning and Review } \\
\text { Process (PARP) }\end{array}$ & Since 2002 & Since 1997 & Since March 1999 \\
\hline $\begin{array}{l}\text { Individual Partnership Ac- } \\
\text { tion Plan (IPAP) endorsed } \\
\text { by the NAC }\end{array}$ & 16 December 2005 & 27 May 2005 & 29 October 2004 \\
\hline
\end{tabular}

38 This is the only part of Abkhazia controlled by the government in Tbilisi. The Abkhaz secessionist leadership in Sukhumi strictly opposed the opening of an office of the NATO Information Center on 26 July 2007. On 3 August 2007, the head of the center, Nanuka Zhorzholiani, declared that another office could be established in Gali in Southern Abkhazia. This, too, was condemned in Sukhumi. 


\begin{tabular}{|c|c|c|c|}
\hline $\begin{array}{l}\text { PfP Status of Forces } \\
\text { Agreement (PfP SOFA) }\end{array}$ & $\begin{array}{l}\text { Signed on } 28 \text { Octo- } \\
\text { ber } 2003 \text {; became } \\
\text { effective on } 16 \text { May } \\
2004\end{array}$ & $\begin{array}{l}\text { Signed on } 15 \\
\text { January 1998; be- } \\
\text { came effective on } \\
2 \text { April } 2000\end{array}$ & $\begin{array}{l}\text { Signed on } 18 \text { July } \\
\text { 1995; became ef- } \\
\text { fective on } 18 \text { June } \\
1997\end{array}$ \\
\hline $\begin{array}{l}\text { Participation in NATO-led } \\
\text { peacekeeping force in } \\
\text { Kosovo (KFOR) }\end{array}$ & $\begin{array}{l}\text { Since February } \\
2004\end{array}$ & $\begin{array}{l}\text { Since October } \\
1999\end{array}$ & Since May 2003 \\
\hline $\begin{array}{l}\text { Participation in the Inter- } \\
\text { national Security Assis- } \\
\text { tance Force (ISAF) in } \\
\text { Afghanistan }\end{array}$ & - & $\begin{array}{l}\text { Since November } \\
2002\end{array}$ & $\begin{array}{l}\text { For a few months in } \\
2004\end{array}$ \\
\hline $\begin{array}{l}\text { Partnership Action Plan } \\
\text { against Terrorism (PAP-T) } \\
\text { as part of the EAPC (2002) }\end{array}$ & Participant & Participant & Participant \\
\hline $\begin{array}{l}\text { Partnership Action Plan on } \\
\text { Defense Institution Build- } \\
\text { ing (PAP-DIB) as part of } \\
\text { the EAPC (2004) }\end{array}$ & Participant & Participant & Participant \\
\hline
\end{tabular}

In August 2003, NATO took over command of the International Security Assistance Force (ISAF) in Afghanistan. As of 1 April 2008, forty Azerbaijani soldiers and one Georgian representative had taken part in the 47,000-strong force (other figures of troop strength for comparison: U.S., 19,000; United Kingdom, 7,750). These contributions have to be considered to be primarily "political," since in military terms they are merely symbolic. But Azerbaijan, Georgia and Ukraine (one participant as of 1 April 2008) are the only CIS members among the forty states committing troops to Afghani$\operatorname{stan}^{39}$

A Georgian contingent was deployed to Afghanistan for several months in 2004, when ISAF temporarily increased its troops during the presidential elections there; a platoon-size Georgian unit from the Sachkere battalion operated with a British battalion in Afghanistan at that time. Also worthy of mention is an agreement about host nation support for and transit of NATO forces and personnel through Georgia via air, road, and rail infrastructure signed by NATO Secretary-General Jaap de Hoop Scheffer and Georgian Foreign Minister Salome Zourabichvili on 2 March 2005. This document provides important logistical support to NATO operations, in particular ISAF.

The United States has allocated resources to effect and guarantee the interoperability of South Caucasian armies with NATO forces. Washington sent field equipment for the Armenian $12^{\text {th }}$ Peacekeeping Battalion to the MoD in Yerevan at the end of July 2007. This was part of a USD 8 million plan by the U.S. Foreign Military Financing

39 International Security Assistance Force; available at www.nato.int/isaf/docu/epub/pdf/ isaf_placemat.pdf (accessed 9 April 2008). 
program to help the Armenian government achieve its goal of developing a NATO-interoperable peacekeeping battalion by $2009 .^{40}$

\section{The "Russian Factor"}

While NATO considers its engagement with the South Caucasus to be an integral part of its overall efforts to provide security and stability in the Euro-Atlantic region, the overwhelming majority within Russia's political, military, and academic elites as well as in the media holds exactly the opposite point of view. According to the Russian perspective, the Alliance plays a predominantly negative role in the world, is considered "aggressive," and is seen as interfering in the internal affairs of the CIS, which should be none of NATO's business. In Moscow, all NATO efforts toward the CIS-and therefore in the South Caucasus as well-are perceived as being principally directed against Russia and its influence in the region. All contacts between CIS republics and NATO are being observed and commented upon in Russia; in the best case, they are viewed with mere mistrust, but more often they meet with open and sharp rejection. For Russia, the accession of a CIS member state to NATO membership is totally out of the question. ${ }^{41}$

In Moscow it is a commonly held view that NATO and its leading power, the United States, are trying to diminish Russia's influence in the South Caucasus, drive a wedge between Russia and Armenia, and achieve the closure of Russian military bases in the South Caucasus. ${ }^{42}$ And, from Moscow's point of view, the association between Georgia, Ukraine, Azerbaijan, and Moldova known as GUAM is a "Trojan Horse” of

40 “U.S. Provides \$3 million of Field Equipment to Armenian Peacekeeping Battalion,” Armradio (1 August 2007); available at www.armradio.am/news/?part=soc\&id=10355 (accessed 28 August 2007).

41 Those positions have been consolidated over the last few years, leading to serious doubts about the efficiency of various confidence building measures, consultations, and negotiations between Brussels and Moscow, especially within the framework of the NATO-Russia Council (from 1997 to 2002 known as the Permanent Joint Council).

42 Russia had delayed its withdrawal from its Georgian military bases for a long time, worrying that NATO might "fill the vacuum" that its departure created, or that Georgia might join the Alliance more easily without the bases. But on 30 May 2005, Moscow and Tbilisi signed a preliminary agreement, according to which Russia has to vacate its two former bases in Batumi and Akhalkalaki by the end of 2008. However, already in November 2007 it was officially announced that Russian forces have completed their withdrawal from their last remaining base in Georgia (Batumi). But a Russian base does remain in the city of Gudauta in breakaway Abkhazia. 
NATO and/or the U.S. seeking to infiltrate the CIS and to constrain their effective "integration" (from the Russian perspective). ${ }^{43}$

Since the second half of the 1990s, various Russian politicians and media outlets have constantly claimed-with or without referring to relevant statements from Baku and Tbilisi-that the opening of NATO bases in Azerbaijan and Georgia would not only be a matter of time, but had practically been already decided, was a simple inevitability, etc. The Alliance, however, has never publicly shown any interest in setting up such facilities, and no statement by any NATO official is on the record stating that a continuation of cooperation with Armenia, Azerbaijan, and Georgia would depend upon or aim at "anti-Russian" measures. Neither this fact nor statements given by thenNATO Secretary-General Robertson-who "welcomed" the Russian military presence in the region ${ }^{44}$ (though not further elaborating on its positive role) and did not perceive any "competition" 45 between NATO and the CSTO regarding security in the regionhave so far helped to diminish Russia's anxiety and opposition.

Georgia was a particular subject of Russian focus due to its emphatic pursuit of NATO membership. In July 2003, an unarmed NATO Airborne Warning and Control System (AWACS) surveillance aircraft undertook a one-hour demonstration flight above Tbilisi. The Russian Foreign Ministry reacted immediately with overwrought statements, and senior Russian military officials publicly discussed the deployment of S-300 air defense systems in secessionist Abkhazia to be able to shoot down AWACS aircraft. ${ }^{46}$ The then-Russian Defense Minister Sergei Ivanov (who was until December 2007 considered as one of the "crown-princes" of President Vladimir Putin) accused Eastern European NATO members of illegally supplying Soviet-made arms to Georgia, and spoke of "piracy." problem was, since no international arms embargo is in place against Georgia. Addi-

43 On 10 October 1997, the presidents of Georgia, Ukraine, Azerbaijan, and Moldova, at a meeting in Strasbourg, signed a communiqué regarding closer cooperation between the four nations. Their informal association was named GUAM, according to the initial letters of the participant states. Russia went to considerable lengths to damage the GUAM association politically, diplomatically, and propagandistically. However, this expenditure was disproportionate to the group's factual importance. It was (and is) neither a formal alliance nor an international organization, but merely - in the best case-a consulting board. An office of GUAM in Kiev only became operational in January 2007. It was never in any way in a position to act as a counterbalance for the CSTO, or even to confront Moscow's hegemonic claims, even though Russian politicians, spin doctors, geopoliticians, senior officers of the armed forces, etc., being permanently anxious regarding GUAM's influence, allege the contrary.

44 Cited in "Glava NATO posetil Azerbaydzhan; on vidit vozmozhnost ukreplenie svyazey" (translation of an AFP report), Kommersant (19 January 2001), 11. $R F E / R L$ Newsline, Vol. 7:92 (16 May 2003).

${ }^{46}$ See Igor Korotchenko, "Genshtab gotovitsya sbivat 'AVAKSy'," Nezavisimaya gazeta (15 July 2003), 1.

47 Cited in Paul Ames, "Ivanov Accuses NATO of Arming Georgians," The Moscow Times (2 October 2006), 2. 
tionally, other high-ranking Russian officials' statements publicly raised doubts about their ability to accurately assess the actual state of affairs Georgia. Thus, the Chief of the General Staff of the Russian Armed Forces, General Yuri Baluevsky, called the impoverished country a "world leader in the area of military development.",48

In February 2007, Russian Foreign Minister Sergei Lavrov pointed out in an interview with a Russian government newspaper that he did not want to let Georgian NATO membership happen. ${ }^{49}$ At that time, Moscow had already taken measures designed to underscore its firmness: in 2006, a boycott was imposed on important Georgian export products, especially wines and the mineral water brand "Borshomi," which had been popular in Russia for decades. ${ }^{50}$ Furthermore, all air, postal, and bank links between Georgia and Russia were interrupted. Thousands of Georgian guest workers were expelled from Russia, and state-controlled Russian media portrayed Georgia in the darkest colors. Many Russian and foreign observers shared the opinion that Moscow aimed at antagonizing the Georgian population against Saakashvili and his pro-NATO course; the Russian political scientist Andrei Zagorski even identified the Russian goal of "regime change" in Tbilisi. ${ }^{51}$ At the same time the Kremlin seemed to have wanted to take the opportunity - once again - to make it clear to NATO that it had better stay out of the South Caucasus, since otherwise only trouble will result.

\section{NATO and the "Frozen Conflicts"}

\section{NATO’s Positions}

NATO representatives in general, and the Secretary-General in particular, have always deferred to the UN and OSCE when asked in Tbilisi and Baku about a possible role for the Alliance in the efforts to solve the "frozen conflicts" in Azerbaijan, namely the situation in the breakaway republic of Nagorno-Karabakh, as well as in Abkhazia and South Ossetia in Georgia. NATO has therefore not participated in the thus far unsuc-

${ }^{48}$ Cited in Russian Ministry of Defense, "V Voennoy Akademii Generalnogo shtaba Vooruzhennykh Sil Rossiyskoy Federatsii proshla vstrecha nachalnika GSh VS RF - pervogo zamestitelya Ministra oborony RF general armii Yuriya Baluevskogo s voennymi attashe inostrannykh gosudarstv,” 14 December 2006; available at www.mil.ru/info/1069/ details/index.shtml?id=19513 (accessed 1 September 2007).

Vladislav Vorobev, "Voyna i MID. Sergey Lavrov otvergaet silovoe reshenie lyubogo krizisa,” Rossiyskaya gazeta (28 February 2007); available at http://www.rg.ru/2007/02/28/ lavrov.html (accessed 28 February 2007). This amounts to the desire of one state to determine another state's membership in an international organization. This in turn is a result of the traditional Russian perception that CIS member states (which, from the Russian viewpoint, constitute the "near abroad") do not enjoy the same sovereignty in matters of domestic and foreign policy as countries of the "far abroad" (the rest of the world) do. Tbilisi launched a "counterstrike" against the Russian wine boycott by hosting a "Day of Georgian Wine" at NATO Headquarters on 15 March 2007. For this reason, a huge Georgian delegation, led by Defense Minister David Kezerashvili, traveled to NATO HQ.

51 Remark made at an event at the National Defense Academy in Vienna in presence of the author, 22 February 2007. 
cessful negotiations over these conflicts, which have been going on for many years. Instead, NATO Secretary-General Lord Robertson explained in an article appearing in the Azerbaijani press in mid-May 2003 that Russia should not be excluded from the efforts to mediate in the South Caucasian conflicts. ${ }^{52}$ However, such an "exclusion" cannot be considered realistic, neither now nor in the near future. And decisions about the format of the negotiations are certainly not a part of NATO's competence.

In November 2006, NATO rejected the planned referendum on independence in South Ossetia, warning that it risked worsening regional unrest. ${ }^{53}$ Nevertheless, the voting took place, and produced the expected results: 99 percent of the votes were counted in favor of independence from Georgia. Thus it was demonstrated - not for the first time, and certainly not for the last-that the most powerful military alliance in the world is not capable of exerting influence on South Caucasian separatists.

In two paragraphs (39 and 43) of its Riga Summit Declaration issued in November 2006, NATO demanded a peaceful solution to the ethno-territorial conflicts in the South Caucasus and in Moldova: "Our nations support the territorial integrity, independence, and sovereignty of Armenia, Azerbaijan, Georgia, and the Republic of Moldova." 54 The spokesman of the Armenian foreign ministry, Vladimir Karapetyan, appeared unimpressed by NATO’s rhetoric, proclaiming: “This can have no influence, since Nagorno-Karabakh has never belonged to the independent nation of Azerbaijan." 55

NATO representatives have argued on many occasions in favor of "peaceful solutions" to the South Caucasian conflicts. ${ }^{56}$ Whether intended or unintended, this signifies a confirmation and strengthening of the status quo, which has persisted for many years, and serves as a key bolster to the de facto independence of Nagorno-Karabakh, Abkhazia, and South Ossetia. But even this stance has not helped to improve NATO's reputation in those areas; in fact, the effect has been quite to the contrary. Mirroring the EU (which is very close to NATO in this regard), NATO nowhere explicitly defines what is understood as a "solution" or is regarded as desirable: An indefinite continuation of the status quo? A (re)integration of the secessionist state-entities into Azerbaijan and Georgia? Or, to the contrary, their international recognition as sovereign states?

${ }^{52}$ RFE/RL Newsline 7:89 (13 May 2003).

53 “NATO Rejects Referendum in Georgia's South Ossetia Region,” The Associated Press (11 November 2006); available at www.iht.com/articles/ap/2006/11/11/europe/EU_GEN_ NATO_Georgia.php (accessed 15 January 2008).

54 NATO Press Release (2006) 150, Riga Summit Declaration, issued by the heads of state and government participating in the meeting of the North Atlantic Council in Riga on 29 November 2006 (29 November 2006); available at http://www.nato.int/docu/pr/2006/p06150e.htm (accessed 23 August 2007).

55 Cited in "Armenien reagiert gelassen auf NATO-Kommuniqué," RIA Novosti (30 November 2006); available at http://de.rian.ru/world/20061130/56255721.html (accessed 2 September 2007).

56 See, for example, de Hoop Scheffer's speech at Tbilisi State University on 4 October 2007; available at www.nato.int/docu/speech/2007/s071004a.html (accessed 5 October 2007). 
Since then, the situation has become even more complicated, as Russia wants to use Kosovo's possible independence as a precedent for what "must" inevitably lead to the recognition of the several pro-Russian separatist proto-states in the CIS, namely Nagorno-Karabakh, South Ossetia, Abkhazia, and (on the territory of Moldova) Transnistria. $^{57}$ NATO Secretary-General Jaap de Hoop Scheffer rejected this linkage in March 2007: "The eventual decision on Kosovo's status cannot serve as a precedent [...] Kosovo is a unique case." At the same time, he reminded Russia that "NATO is not involved in the process of determining Kosovo's status. This issue is for the UN Security Council, in which Russia, among others, plays a decisive role."58 Nobody within NATO (at least officially) dared to refer to Russia's own struggle against separatist forces in Chechnya, which has been raging since 1994.

\section{Consequences of NATO Membership Ambitions}

As a condition of membership, NATO accession candidates must not have any "territorial problems” or disputes with neighbor states. This does apparently not apply in the cases of Georgia and Azerbaijan, since the power of the state does not encompass the entire territory claimed by its government. In Baku, awareness about the consequences of this condition seems to be higher than in Tbilisi. Thus, Azerbaijani Deputy Foreign Minister Araz Azimov, referring to Nagorno-Karabakh, admitted that he does not see "any chance for a country engaged in such a territorial conflict" to become a member of NATO. ${ }^{59}$

Georgia hopes that, "once it becomes part of the Alliance, it will be harder for Russia to influence the processes in Abkhazia and South Ossetia." ${ }^{, 60}$ Russia for its part is aware that the "frozen conflicts" in Abkhazia and South Ossetia severely affect Georgia's NATO ambitions. Consequently, Moscow is trying to prevent at any cost a return of Abkhazia and South Ossetia to a position that places them under the authority of the Georgian state. The spokesperson of the Russian Foreign Ministry, Mikhail Kamynin, announced in April 2007 that Georgia's intensive preparations for NATO membership are "undermining the negotiations on settlement of the Georgian-Ossetian and Georgian-Abkhaz conflicts and the very principle of territorial integrity." ${ }^{1}$ Before that, the nationalist hardliner and pro-Kremlin spin doctor Konstantin Zatulin, director of the

57 The sources of such an "automatism" in international law and politics remain unclear, as does the question of why Chechnya in turn would not "have" to be granted independence by Russia.

58 Cited in Interfax (22 March 2007), via Johnson’s Russia List, 2007-70 (23 March 2007).

59 Cited in Liz Fuller, “Azerbaijan: Baku Seems Ambivalent About NATO Membership," RFE/RL Features Article (22 March 2007).

60 Kakha Jibladze, “Russia’s Opposition to Georgia’s Quest for NATO Membership,” China and Eurasia Quarterly 5:1 (2007): 46.

61 Cited in "Russia, EU Ambassadors Discuss Conflicts in Georgia,” Itar-Tass (24 April 2007); available at www.itar-tass.com/eng/level2.html?NewsID=11467768\&PageNum=0 (accessed 25 April 2007). 
Moscow-based Institute of CIS Countries, even had more articulately formulated that Georgia's accession to NATO equaled a "prologue to the country's breakup.,"62

Russian politicians and observers critically commented on the plebiscite about NATO membership in Georgia mentioned above. Thus, Aleksei Ostrovsky, head of the Committee on CIS Affairs and Relations with Compatriots of the State Duma (Lower House of Parliament), called the official results "rather dubious in the light of assessments made by Russian observers." ${ }^{\text {"3 }}$ Dmitri Rogozin, Russia’s permanent representative to NATO and a hard-core nationalist, said that "the very idea of holding a referendum on Georgia joining NATO was a big political mistake” on the part of Saakashvili. Rogozin pointed out that neither Abkhazia nor South Ossetia had voted for Georgia to join NATO, and therefore they were freed from the responsibility of making the decision. According to this logic, by going ahead with the referendum despite knowing that the separatist regions would not take part, Saakashvili "thereby himself supported the separatist ambitions of South Ossetia and Abkhazia."64 Sergei Markov, the director of the Political Research Institute and a State Duma deputy from the pro-Kremlin-party "Unified Russia," said that, despite the results of the referendum, Georgia has no chances to join the Alliance in the foreseeable future: "There are some NATO members that will not want to quarrel with Russia and will veto this accession." 65 Markov is a highly emotional figure with a controversial reputation, but this assessment turned out to be correct at NATO's Bucharest Summit in April 2008. Already on 21 March 2008 the State Duma passed a resolution calling on the Kremlin to consider recognizing the "independence" of the Georgian breakaway territories of Abkhazia and South Ossetia if Georgia joins NATO. ${ }^{66}$

These Russian statements, and countless others like them, could suggest that a simple abandonment of ambitions to NATO membership may accelerate or make more likely Abkhazia and South Ossetia's integration into the Georgian state. However, this is not the case, due to many reasons. One of them can be illustrated through the example of Azerbaijan: As discussed above, although it does not pursue NATO membership, it still does not seem to have any better chance of regaining control over Nagorno-Karabakh.

\section{NATO Assistance Against Secessionists?}

NATO has never discussed any military intervention in the South Caucasus, no matter where and on which side, and correlative scenarios-even when presented with great

62 “Georgia’s Accession to NATO May Break up the Country,” Pravda (22 May 2003); available at http://groong.usc.edu/news/msg68938.html (accessed 26 May 2003).

63 Cited in "Georgian Referendum on NATO Fires Separatist Sentiment, Says Russian NATO Envoy,” Interfax (11 January 2008), via Johnson’s Russia List, 2008-9 (14 January 2008). Ibid.

65 See “Georgia Will Be Unable to Join NATO_Russian Analyst,” Interfax (11 January 2008), via Johnson’s Russia List, 2008-9 (14 January 2008).

66 “Russia: Duma Votes to Back Separatist Efforts in Georgia,” RFE/RL Features Article (22 March 2008). 
seriousness - seem only bizarre. Nevertheless, politicians made use of such specters, especially during the NATO intervention against rump Yugoslavia in early 1999 in response to the mass evictions of Kosovo Albanians from Kosovo. On the occasion of NATO's fiftieth anniversary, a glossy brochure was published in Baku, including several positive statements by Azerbaijan's President Heydar Aliev concerning the Alliance. Therein it was made clear that he was expecting aid from NATO against Armenia. ${ }^{67}$ Additionally, he stated: "Independent organizations including NATO have yet to recognize Armenia as the aggressor and have taken no concrete steps to ensure that justice prevails, as they did in Kosovo." ${ }^{\circ 8}$ Amayak Ovanesyan, member of the Armenian Parliament and chairman of an association of political scientists, ${ }^{69}$ saw NATO as posing a danger to the security of Karabakh. ${ }^{70}$ Obviously, he suspected the Alliance of providing assistance to Azerbaijan in a hypothetical military operation.

In 1999, speculations about NATO's assistance for Georgia to recapture Abkhazia appeared persistently, above all in the Russian press, but also in Abkhazia. Later, several Russian and Abkhaz commentators suggested that the abovementioned NATO/ PfP-exercise "Cooperative Partner 2001" was a rehearsal for a Georgian attack on Abkhazia. ${ }^{71}$ Additionally, the "CIS peacekeeping forces" (consisting of only Russian military units) in the Georgian-Abkhazian conflict zone at the Inguri River believe that they must be prepared for a NATO invasion. Their commander, Major-General Nikolai Sidorovich, said on 14 June 2001 that, with 2,000 men, his force is strong enough to repulse any incursion by combined NATO and Georgian forces. ${ }^{72}$ Sanobar Shermatova, an insider on the southern periphery of the CIS, surmised that Abkhazia is seriously preparing to "avert a Georgian-American invasion by its own means."73

The AWACS flight over Tbilisi discussed above was seen by secessionist Abkhazia as a possible first signal of the "direct involvement of NATO forces in the GeorgianAbkhazian conflict."74 The Abkhaz separatist leader Sergei Bagapsh stated in 2007: "We will increasingly arm ourselves as we know well what happens if Georgia joins

67 Secretariat of the President of the Republic of Azerbaijan, "NATO and AzerbaijanMutually Beneficial Cooperation” (Baku, 1999), 18, 20-21, 33.

${ }^{68}$ Cited in Ara Tadevosian, "NATO Refuses to Take Sides. A NATO trip to Armenia and Azerbaijan proves disappointing for both countries," IWPR's Caucasus Reporting Service, No. 67 (29 January 2000).

69 Armenian observers contacted by the author could not name anybody who would be a member of this association besides Ovanesyan.

70 Cited in Olga Allenova, “Armyanskaya oppozitsiya gotova k falsifikatsii,” Kommersant (11 May 2007), 5.

71 "NATO Exercises in Georgia," Security Watch (20 June 2002); "Georgian Embassy in Moscow Protests ‘Izvestiya’ Allegations,” RFE/RL Newsline (18 June 2001).

72 RFE/RL Newsline (15 June 2001).

73 Sanobar Shermatova, “Strana so znakom GTO,” Moskovskie novosti, 11 (2002); available at www.mn.ru/issue.php?2002-11-19 (accessed 2 September 2007).

74 Anatoliy Gordienko, Igor Korotchenko, "Kvashnin vse-taki protalkivaet sistemu S-300 v Abchaziyu,” Nezavisimaya gazeta (21 July 2003); available at www.ng.ru/printed/40466 (accessed 2 September 2007). 
NATO. And we understand who will appear in the conflict zone."75 Russian officials expressed similar fears. Thus, the Russian Ambassador to Georgia, Vyacheslav Kovalenko, explained that Georgian NATO membership would strengthen the apprehensions in Abkhazia and South Ossetia concerning the measures that Tbilisi "wants to grasp.” They could be "assured in their feeling that Georgia is aiming at a military solution of the conflict."76 Thus NATO was apparently judged to be willing to either tacitly favor or materially support a Georgian campaign in Abkhazia and South Ossetia. It remains unclear how this attitude can plausibly be held in a country which itself has been fighting a bloody war that has caused tens of thousands of civilian casualties since 1994 against Chechen separatists that it only refers to as "terrorists," and with whom it has rejected any overtures to negotiation.

Already, during the Shevardnadze era, Georgia wanted to see the "CIS peacekeepers" at the Inguri River, who lack any UN mandate, be replaced by contingents from other countries, such as Ukraine and/or Turkey, or even by a NATO or EU peacekeeping force. But Russia and Abkhazia always unconditionally rejected such proposals, and NATO did not display any further interest. Thus, in October 2006, the Chairman of the NATO Military Committee, General Raymond Henault, made it clear that the Alliance has no intention to send peacekeeping forces to the Georgian breakaway regions. Concerning Nagorno-Karabakh, the question does not even appear theoretically: the Armenian-Azerbaijani ceasefire has been complied with (despite minor incidents) since May 1994 without the presence of any peacekeepers.

\section{Summary and Conclusions}

The more or less enthusiastic messages that have been spread to varying degrees by the administrations of all three South Caucasian republics-most intensely in Georgia, least enthusiastically in Armenia-regarding cooperation with NATO often do not permit judgment about the necessity for and effectiveness of such cooperation. It is difficult to ignore the significant incongruity between the optimistic statements of South Caucasian (especially Georgian) politicians concerning the realism of achieving NATO standards on the one hand and the actual condition of the region's armies, as documented by several foreign and domestic observers, on the other hand.

Armenia, Azerbaijan, and Georgia pursue different aims regarding NATO, a state of affairs that will probably not change in the near future. The South Caucasian "climate of opinion" toward NATO is sunniest in Georgia, and gloomiest in Armenia. ${ }^{77}$

${ }^{75}$ Cited in Svetlana Gamova, "Ushchele na dvoikh," NG-Dipkurer (supplement to Nezavizimaya gazeta) (19 March 2007): 15.

76 "NATO-Beitritt Georgiens erschwert Konfliktlösung im Kaukasus,” RIA Novosti (12 March 2007); available at http://de.rian.ru/postsowjetischen/20070312/61862088.html (accessed 13 March 2007).

77 For different reasons, opinion polls in the region should be viewed with even greater caution than in Western Europe or North America. Thus it is legitimate to question their validity, when several competent (Caucasian and other) observers say that the persons interviewed have only limited (or no) knowledge of the matter concerned. 
Even apart from this wide divergence in views of NATO within the region, the accession of the South Caucasian states to NATO membership is not an option for the immediate future. Thus it is rejected by Russia and Iran, and the Alliance is unlikely to strain the already tense relations with Moscow over a region that is not familiar to the Western European and American public, and which is not supposed to be of predominant importance.

In addition, it is hard to imagine how Georgia and Azerbaijan-whose governments exert only partial controlling over their territories - expect to join a military alliance. Tbilisi and Baku have obviously been mistaken if they hoped for NATO's assistance to regain control over Abkhazia, South Ossetia, and Nagorno-Karabakh respectively. The Alliance has until now not taken any steps in this direction, and has not even sought a role in the negotiation process. In fact, it has not even addressed the fact of occupation of Georgian and Azerbaijani soil.

Azerbaijan's President Ilkham Aliev has stated time and again that a solution of the Karabakh conflict is not possible without the inclusion of EU and NATO ${ }^{78}$ Nevertheless, a solution is also not likely to materialize within either of these organizations, since the root problem of the South Caucasian "frozen conflicts" does not lie in the format of the negotiations, but in the two sides' apparently mutually exclusive claims: While Baku and Tbilisi assert the international law principle of territorial integrity (within the borders of the former Azerbaijani and Georgian Soviet republics), Abkhazia, South Ossetia, and Nagorno-Karabakh insist that their territorial separation be allowed, and actually demand that their causes be covered by their specific interpretation of the principle of the self-determination of peoples.

Georgia felt affirmed in its ambitions toward NATO membership due to repeated violations of its airspace by Russian military aircraft (which were confirmed by international observers and commissions). Russia has always strictly rejected these Georgian allegations, and insinuated that Tbilisi is only searching for reasons that will help to draw NATO to its side. At present, this looks exactly like what Tbilisi is hoping will happen, but this naturally does not mean that it will work out as planned; NATO's desire to protect Georgia and to prepare for a military clash with an increasingly self-confident Russia appears to be very small. ${ }^{79}$ Georgia was granted an "Intensified Dialogue on Membership Aspirations" by the North Atlantic Council in 2006, but at the same time NATO clarified this step: "This does not guarantee an invitation to join the Alli-

${ }^{78}$ Aleksandr Gabuev, “V Azerbaydzhan so svoim Karabakhom,” Kommersant (22 May 2007): 9.

79 According to Abid Sharifov, Deputy Prime Minister of Azerbaijan, NATO rejected two joint requests from Georgia, Azerbaijan, and Turkey to deliver technology needed to provide security for the Baku-Tbilisi-Ceyhan oil pipeline; see RFE/RL Newsline, 11:204, Part I (2 November 2007). This, again, demonstrated the Alliance's desire to stay out of any potential conflicts in the South Caucasian region. 
ance, but it is a clear signal from the Allies that they support Georgia's membership aspirations." ${ }^{, 0}$

Georgia's accession to NATO membership in the near future is "very unlikely,", regardless of its desirability. This assessment gained even more significance in the light of Jaap de Hoop Scheffer's statement at the occasion of the imposition of emergency rule during a political crisis in Georgia in November 2007, which he called "not in line with Euro-Atlantic values." 82 Emergency rule lasted only for a week, but nevertheless many observers agreed that Saakashvili has severely damaged Georgia's chances of winning a promise of membership at NATO's summit in April 2008 in Bucharest.

A number of statements from NATO and EU representatives suffer from the perception of the South Caucasus as a single, unified entity and the willingness to treat it as such, thereby leaving aside all differences and contrasts between the countries and peoples in the region. Bearing in mind this background, the danger of making poor decisions is naturally high. Already confronted with the expensive, complex, and unpopular engagements in the Western Balkans and Afghanistan, the resources and the willingness of NATO to deepen its activities in the South Caucasus are likewise small. Therefore the region will retain its comparatively minor importance for the Alliance in the foreseeable future.

The following disclaimer dates back to 2003: "NATO managed to address only peripherally the main security threats and challenges affecting countries in the regioni.e., unresolved conflicts, open borders, weak and corrupt state structures, inefficient armed forces, and arms and drug smuggling." ${ }^{23}$ This is indeed the case, but the Alliance in its self-conception is not responsible for the solution of the bulk of these problems. Due to this and many other reasons, these threats will likely haunt the South Caucasus for a fairly long time to come.

Completed in April 2008

80 NATO, “NATO-Georgia Relations,” 7 August 2007; available at www.nato.int/issues/natogeorgia/index.html (accessed 17 August 2007).

81 Gulbaat Rzchiladse, “Rußland und Georgien. Konfrontation statt Kooperation,” Osteuropa, 7:57 (2007): 71-80, quoted passage at 75.

82 NATO Press Release (2007) 114, Statement by the Secretary-General on the Situation in Georgia, (8 November 2007); available at www.nato.int/docu/pr/2007/p07-114e.html (accessed 21 November 2007). The chief of the General Staff of the Russian armed forces, General Yury Baluevsky, held NATO “partly” responsible for the crisis in Georgia; however, he did not elaborate. See RFE/RL Newsline 11:210, Part I (13 November 2007).

83 Domitilla Sagramoso, “The UN, the OSCE and NATO," in The South Caucasus: A Challenge for the EU, Chaillot Papers, no. 65, ed. Dov Lynch (Paris: Institute for Security Studies, December 2003), 63-89, cited passage at 85. 
THE QUARTERLY JOURNAL

\section{Bibliography}

Dzlieradze, Dursun. "Georgia: NATO Hopes on Hold." IWPR's Caucasus Reporting Service 106 (2001).

Mamedov, Jasur. November IWPR's Caucasus Reporting Service In Azerbaijan Tiptoes Towards NATO., 2006.

Vignanskiy, Mikhail. "Gamardzhoba, NATO! Gruziya vstupaet v Alyans otdelno ot sobstvennoy armii." Vremya Novostey (2002). 